\title{
Abstracts
}

\begin{abstract}
A. James Arnold, Césaire is Dead: Long Live Césaire! Recuperations and Reparations
\end{abstract}

Events surrounding Aimé Césaire's funeral in Martinique (April 2008) brought to the fore a number of unresolved contradictions that have swirled around his literary production, as well as his political legacy, for decades. Did Césaire really mean to speak for a culturally and historically determined group of dispossessed colonials and former colonials, as he often stated from the 1960s onward? Or did he intend to appeal to a biologically determined collective unconscious, as he sometimes stated in less guarded moments? Finally, should Césaire's ambiguous statements about the movement to require reparations from the French state for centuries of enslavement in the Antilles be taken as an endorsement of such demands? None of these questions were resolved in the flood of writing about Césaire's importance and significance in the year of his death.

Keywords: Césaire, Martinique, négritude, reparations, legacy

Fred Reno, Aimé Césaire ou l'ambivalence féconde [in French]

Critics question the articulation between Césaire's immense literary works and his comparatively modest political legacy. They contend that the ferociousness of his case against slavery and colonialism clashes with the tepid way in which he tiptoed the Martinican people onto its political route, cautiously steering clear of the full-fledged self-rule option. The case I am making in this paper is that it would be terribly misleading, let alone unfair, to assume that Césaire was all lip-service, La Lettre à Maurice Thorez being a case in point. Rather, Césaire's political genius is to have managed to take his ideals down a few pegs to be in tune with the people, because he knew as a poet that emancipation is not a place to reach but a way to walk. In that respect, Césaire implemented what I have come to conceptualize as "dependence-resource."

Keywords: ambivalence, colonialism, departementalization, dependenceresource, French citizenship 
Justin Daniel, Aimé Césaire et les Antilles françaises: Une histoire inachevée? [in French]

The double commitment of Aimé Césaire on the political and literary fronts as well as the comparison between his achievements in these two fields of activity have drawn various interpretations, often impassioned. This contribution proposes to throw light on some apparent or real paradoxes that underlie his political thought and action. It also tries to evaluate his role through his literary commitment and his investment in the political field by taking into account the specific logics at work in each of these spheres, without neglecting their own temporality, as well as their possible contradictions or complementarities.

Keywords: colonization, literature, négritude, political assimilation, political autonomy

Fred Constant, Aimé Césaire et la politique: Sept leçons de leadership [in French]

The Caribbean has yielded many leaders with statesmanship abilities that are on par with the very best in the world; it is to one of these that the present essay is devoted. Specifically, it attempts to understand the nature of the political leadership that Aimé Césaire has epitomized for more than fifty years in his native Martinique and abroad. In doing so, it examines what accounts for his political appeal and his capacity to pursue his political vision. The essay also suggests some insights that the rest of the world could draw from Césaire's experience.

Keywords: Caribbean, politics, leadership, identity, postcolonialism

Tyler Stovall, Aimé Césaire and the Making of Black Paris

This article considers how the life of Aimé Césaire constitutes a template for the black presence in Paris. It concentrates on three themes: Paris as a (conflicted) symbol of liberty; Paris as an artistic and intellectual center; and Paris as a global city. It shows how, as the life of Césaire exemplifies, the black communities of Paris have seen the French capital as both a site of diasporic encounters and as a beacon of liberty. Like Césaire, the black presence in Paris has both challenged and underscored traditions of French universalism.

Keywords: Aimé Césaire, liberty, Martinique, Paris, African diaspora

Thomas A. Hale and Kora Véron, Aimé Césaire's Break from the Parti communiste français: Nouveaux élans, nouveaux défis

Aimé Césaire's dramatic break from the French Communist Party in 1956 raises questions not only about the reasons for his resignation, but more importantly, about how he overcame the negative consequences of the rupture to give a new impetus to his career as the principal political leader in 
Martinique. A close examination of his writings from 1945 to 1959, based especially on his lesser-known declarations, essays, interviews, and speeches, as well as on his more widely-disseminated poetry and history, reveals a more nuanced explanation for the rupture. Above all, these texts offer new insights into how he was able to recover his political momentum by building new alliances both at home and abroad.

Keywords: Aimé Césaire, Martinique, French Communist Party, France, Parti progressiste martiniquais

William F.S. Miles, "Metaphysical Considerations Can Come Later, But the People Have Children to Feed": An Interview with Aimé Césaire

Nineteen eighty-two marked a milestone in the history of Martinique and the career of Aimé Césaire. One year had passed since François Mitterrand's election as president and Césaire's declaration of a "moratorium" on challenging the island's status as a French département (state). Pro-independence violence still rocked the French West Indies. In this interview Césaire discusses the burdens of material dependency, dangers of in- and out-migration, centralizing legacies of France, opportunities afforded by Socialist governance, the need for decentralization, and the future of Martinican identity. The interview reveals Césaire's strategic flexibility within inviolate principles, his unique capacity to channel his people's psyche, his keen recognition of the relationship between nationalism and economics, and his sensitivity to micropolitics and intraisland differences.

Keywords: Martinique, négritude, French West Indies, departmentalization, autonomy

Nathalie Etoke, Au bout du petit matin... J'ai la force de regarder demain [in French]

This essay is an intimate account of my encounter with Aimé Césaire. I first met him in high school. I was seventeen years old, and I had never read any work comparable to his Notebook of a Return to the Native Land. That book left me confused. The more I read the less I understood. A student in lettres modernes at Université Charles De Gaulle, I became tormented by identity issues. My years in France introduced me to racism, to an other who observed me without seeing me-between us centuries of violence, stereotypes, misunderstanding, unrequited love, unresolved conflict, unshared suffering. How do you get rid of the cutting glance that murders the Promise of Tomorrow? Césaire gave me an answer to that question.

Keywords: Aimé Césaire, encounter, identity, black suffering, existential poetics 
Francis Abiola Irele, The Poetic Legacy of Aimé Césaire This essay examines the centrality of Aimé Césaire's work in the emergence of a black poetic and intellectual discourse in French, and his influence, in terms both of theme and idiom, on generations of Francophone writers, an influence that can be discerned in the work of Tchikaya $u$ Tamsi, Jean-Baptiste TatiLoutard, Lamine Sall and Sylvie Kandé in Africa, and Frantz Fanon, Edouard Glissant, René Depestre, and Daniel Maximin in the French Caribbean region. The relationship of Césaire's work to the Créolité movement is discussed, as is the impact of his work on Anglophone Caribbean writers, such as Kamau Brathwaite of Barbados and Lansana Sekou of St Martin, as evidence of the enduring legacy of his work.

Keywords: Negritude, Tchikaya, Depestre, Antillanité, Créolité

Ronnie Scharfman, Aimé Césaire: Revisiting the Poetry

In July 1989, as part of the celebration of the Bicentennial of the French Revolution, the great Martinican poet, playwright, and essayist Aimé Césaire was a special invitee of the Avignon Theatre Festival. I led a round table with him then in the context of the Institut d'Études Françaises of Bryn Mawr College. In his remarks he also read two unpublished poems. One of them, "Parcours," which I translate here as "Journey," is the subject of this article. This piece constitutes a reading of the poem as the poet's looking back, metaphorically, on his poetic journey, fifty years after the publishing of his epic poem, "Cahier d'un retour au pays natal" in 1939. This theme of looking back becomes a way to meditate on my own intellectual trajectory as a scholar of Césaire's poetry. I conclude with a poem of my own, on "Rereading Césaire Thirty Years On." Keywords: Aimé Césaire, Parcours, négritude, Bicentennial of the French Revolution, Avignon Theatre Festival 


\section{CALL FOR SUBMISSIONS}

\section{LAURENCE WYLIE PRIZE IN FRENCH CULTURAL STUDIES \\ 2008-09}

Created in 1995 to honor the memory of Laurence Wylie, Professor of French Civilization at Harvard University, the Laurence Wylie Prize in French Cultural Studies is awarded every second year to the best book in French social or cultural studies. Nominated books must be scholarly essays dealing with French society or culture published in 2008 or 2009 (fiction and literary criticism are excluded). Books may be written in English or French, but the author must reside in North America. The 2006-08 Wylie Prize was awarded to Rebecca DeRoo (Washington University) for her book The Museum Establishment and Contemporary Art: The Politics of Artistic Display in France after 1968 (Cambridge University Press, 2006).

The deadline for submissions is January 30, 2010. The prize will be announced in the spring of 2010 and awarded at NYU the following fall. Presses may submit more than one book. For further inquiries, please contact the Prize Committee Chair, Stéphane Gerson (stephane.gerson@nyu.edu). Please send a copy of each nominated book to the members of the Prize Committee (total of four copies):

Prof. Tom Conley

Dept. of Romance

Languages \& Literatures

Harvard University

Boylston Hall, $4^{\text {th }}$ floor

Cambridge, MA 02138

Prof. Stéphane Gerson

Department of French

New York University

19 University Place, $6^{\text {th }}$ floor

New York, NY 10003
Prof. Laurent Dubois

Professor of History and

Romance Studies

205 Language Center, Box 90257

Duke University

Durham, NC 27708-0257

Prof. Brigitte Lane

c/o Dept. of Romance Languages

Rm 212 - Olin Center

Tufts University

Medford, MA 02155 